\title{
Ser Irmão de uma Criança com Asma/Bronquite na Perspectiva Hermenêutica
}

\author{
Matos, Ana Paula Keller de; Abreu, Flávia Correa Porto de; Wernet, Monika \\ Universidade Federal de São Carlos — anakeller@gmail.com
}

Introdução: a asma é uma das doenças crônicas mais comuns no mundo, e a mais comum em crianças. no Brasil, estima-se que a prevalência dela seja por volta de $10 \%$. a literatura quando traz informações sobre a bronquite, a associa à asma, e muitas vezes bronquite $e$ asma são usados como termos sinônimos. a asma/bronquite exige demandas de cuidado que impactam a família, com repercussões a vários de seus membros, inclusive o irmão da criança doente. Poucas pesquisas tem acessado a perspectiva do irmão da criança com asma/ bronquite com vistas à compreender a experiência fraterna na voz do próprio irmão, e no intuito de agregar conhecimento neste sentido, foi desenvolvida esta pesquisa. Objetivo: Compreender a experiência de irmãos que convivem com crianças com asma ou bronquite. Método: Pesquisa exploratória, qualitativa, pautada no referencial teórico e metodológico da hermenêutica filosófica de Gadamer. Oito crianças/adolescentes, irmãs(ãos) mais velhos de crianças com asma ou bronquite, com idades entre seis e 16 anos, integraram o estudo. a coleta dos dados deu-se por meio de entrevistas abertas integradas às estratégias de desenho, cartas ou fotografias. Foram seguidas as cinco etapas propostas por pesquisadores em Glasgow, que adotam a perspectiva gadameriana como estrutura para analisar dados. Resultados: a compreensão advinda da análise dos diálogos foi a de que o irmão valoriza a relação fraterna e a sobrepõe às repercussões da asma/bronquite da criança em sua vida. a irmandade é marcada pela união, companheirismo, amizade e proteção, onde a simples presença da criança na vida do irmão é entendida como felicidade. em seu cotidiano, os irmãos exercem ações de cuidado/proteção à criança doente crônica determinadas pela dinâmica da família. Nesta situação, contam com escassas fontes de informação sobre a doença da criança, e anseiam por poder obter mais conhecimento da mesma. Eles assumem responsabilidades de cuidado à criança como medicar, vigiar, cuidado ambiental e prevenção de riscos de agudização da doença. Sentem diferenças no tratamento ofertado pelos pais em relação a ele e ao irmão. e apesar de terem suas próprias demandas, estas não são percebidas e o enfrentamento das mesmas é realizado de forma solitária, sustentada por um movimento de ponderar sua situação e encontrar acalento para aquilo que o faz sofrer. Tal processo permite a ele entender sua vida como "normal". Conclusão: Os achados ressaltam a invisibilidade do irmão de crianças com asma/bronquite, o que implica em necessidade de transformação de práticas profissionais, com vistas ao cuidado integral. Isso demanda transformações em cenários de ensino, formação e pesquisa. Não há como cuidar de forma humanizada percorrendo caminhos "retilíneos", "pré-determinados" e isentos de fusões de horizontes, sem abertura para o encontro com o outro através do diálogo.

Matos, Ana Paula Keller de; Abreu, Flávia Correa Porto de; Wernet, Monika. Ser Irmão de uma Criança com Asma/Bronquite na Perspectiva Hermenêutica.. In: Anais do Congresso Internacional de Humanidades \& Humanização em Saúde [= Blucher Medical Proceedings, num.2, vol.1]. São Paulo: Editora Blucher, 2014. ISSN 2357-7282

DOI 10.5151/medpro-cihhs-10721 